\title{
イチゴ輸送中の衝撃解析と損傷発生予測
}

\author{
北澤裕明 ${ }^{1} \cdot$ 石川 豊 ${ }^{1 *} \cdot$ 路 $\quad$ 飛 $^{1} \cdot$ 胡 $\quad$ 耀華 ${ }^{2} \cdot$ 中村宣貴 ${ }^{1} \cdot$ 椎名武夫 ${ }^{1}$ \\ ${ }^{1}$ 独立行政法人農業・食品産業技術総合研究機構食品総合研究所 305-8642 荻城県つくば市観音台 \\ 2 西北農林科技大学機械電子工程学院 712100 中華人民共和国陝西省楊凌区西農路
}

\section{Analysis of Shock during Strawberry Transport and Damage Estimation}

\author{
Hiroaki Kitazawa $^{1}$, Yutaka Ishikawa ${ }^{1 *}$, Fei Lu${ }^{1}$, Yaohua $\mathrm{Hu}^{2}$, Nobutaka Nakamura ${ }^{1}$ and Takeo Shiina ${ }^{1}$ \\ ${ }^{I}$ National Food Research Institute, National Agriculture and Food Research Organization, Kannondai, Tsukuba, Ibaraki 305-8642 \\ ${ }^{2}$ College of Mechanical and Electronic Engineering, Northwest Agriculture and Forestry University, Xinong Road, Yangling District, Shaanxi Province \\ 712100 People's Republic of China
}

\begin{abstract}
To determine preventive measures for strawberry damage from shock during transport, we measured the shock frequency and level during actual transport using an acceleration recorder and determined these effects on the commercial quality of fruit. In addition, we investigated cushioning materials for use in reducing both shock and quality loss during transport. Shock was found to be concentrated in the bottom layer of boxes. The effect of shock severity and frequency on quality could be shown as a power approximate curve $\left(\mathrm{R}^{2}=0.98\right)$ and used to deduce quality loss from shock. Using this curve, the relationship between thickness of cushioning materials and the degree of reduction in quality loss of the fruit was determined. Based on these findings, packaging could be designed to reduce damage caused by shock during strawberry transport.
\end{abstract}

Key Words : acceleration, cushioning materials, export, packaging

キーワード：緩衝材，加速度，包装，輸出

\section{緒 言}

道路環境の整備や輸送トラックの性能向上（臼田ら, 2006）などにより，輸送工程における青果物の損傷は以前 と比較し, 軽減されつつあると考えられる. しかし, 軟弱 果実の代表的存在であるイチゴに拉いては, その輸送工程 に拈ける果実の損傷が依然として問題となっている（中村 ら, 2007, 2008). 近年では九州産の “福岡 S6 号”（商標名： あま抢ら）が首都圏へ出荷されるなど，国内に打けるイチ ゴの輸送距離は従来と比較し, 長くなる傾向にあるが（中 村ら, 2007), 輸送距離の増加によりイチゴが振動预よび衝 撃を受ける機会が増加している可能性も考えられる.さら に，近年イチゴの海外への輸出が拡大されつつあるが（農 林水産省, 2009), 青果物の海外への輸送工程に拈いては, 国内向けの輸送で想定される以上の振動および衝撃が発生 することが報告されている（Ishikawa ら，2009）。これらを 踏まえると, イチゴの輸送工程における損傷が今後より一

2009 年 5 月 1 日 受付. 2009 年 8 月 25 日 受理.

本研究は新たな農林水産政策を推進する実用技術開発事業（課 題番号 1913）により行われ，一部は園芸学会平成 21 年度春季 大会で発表した.

*Corresponding author. E-mail: yishi@affrc.go.jp
層問題となる可能性も懸念され，輸送工程に打ける振動括 よび衝撃発生状況を詳細に解明するとともに，得られた知 見に基づいた損傷防止のための緩衝包装設計が急務である と考えられる.

振動がイチゴの損傷発生に及ぼす影響に関しては, これま でに S-N 曲線理論の応用による損傷発生理論の構築（岩元 ら，1980）や輸送振動を考慮した緩衝包装設計（北澤ら, 2008; Singh, 1992）などの研究が行われてきた. しかし，イ チゴにおいて衝撃の影響を詳細に解明し, その対策について 研究した例はほとんど無い，一方，Ishikawaら（2009）は才 ウトウの輸送工程に打ける振動扣よび衝撃の解析を行い, 輸 送中の衝撃が果実の損傷発生の主要因となっていることを 示唆しており,イチゴにおいても輸送工程における衝撃が損 傷発生の大きな要因となっている可能性が考えられた.

本研究ではイチゴの損傷発生に及ぼす衝撃の影響に着目 し，実際のイチゴの輸送工程に打ける衝撃発生状況を調査 するとともに，イチゴの損傷に及ぼす衝撃加速度および衝 撃繰り返し回数の影響を調査した。 さらに，想定される衝 撃加速度扣よび衝撃繰り返し回数に対応した緩衝包装設計 のために，厚さの異なる緩衝材を箱内底面に配置した際に おける衝撃および果実損傷の軽減効果を検討した。 
第 1 表 調査対象としたイチゴの輸送経路

\begin{tabular}{|c|c|c|c|}
\hline 日時 & （日本時間） & 行程 & 輸送手段 \\
\hline $1 / 24$ & $\begin{array}{l}5: 00- \\
8: 50\end{array}$ & $\begin{array}{l}\text { 梱包・発送準備（福岡県久留米市） } \\
\text { 宅配業者（福岡県久留米市）へ持ち込み }\end{array}$ & \\
\hline & $13: 30$ 頃 & 宅配業者発 & トラック \\
\hline $1 / 26$ & $9: 22$ & 大田市場 (東京都大田区) 到着 & \\
\hline \multirow[t]{2}{*}{$1 / 27$} & $10: 54$ & 大田市場発 & \\
\hline & $\begin{array}{l}12: 03 \\
20: 00\end{array}$ & $\begin{array}{l}\text { 成田国際空港 (千葉県成田市) 到着 } \\
\text { 成田国際空港発 }\end{array}$ & トラック \\
\hline \multirow[t]{2}{*}{$1 / 28$} & $\begin{array}{l}2: 30 \text { 頃 } \\
17: 05\end{array}$ & $\begin{array}{l}\text { スワンナプーム国際空港（タイ王国サムットプラーカーン県）到着 } \\
\text { スワンナプーム国際空港発 }\end{array}$ & 飛行機 \\
\hline & $21: 00$ & 現地販売店（タイ王国バンコク都）にて着荷確認 & トラック \\
\hline
\end{tabular}

\section{材料および方法}

\section{1. 輸送工程における衝撃発生状況の調査（実験 1） \\ 1) 輸送経路}

2009 年 1 月 $24 \sim 28$ 日にかけて, 福岡県久留米市内から タイ王国バンコク都内までイチゴを輸送した際に発生する 衝撃加速度和よび衝撃発生回数を調査した. 輸送経路の詳 細掞よび各行程における輸送手段を第 1 表に示す.

\section{2) 衝撃計測方法}

供試した包装形態は, イチゴを 9〜 15 個ずつ詰めた発泡 ポリエチレン製ソフトパックを段ボール箱（JIS Z1507, 0425）に 2 個ずつ梱包し, さらにこの段ボール箱を 4 個積 み重ねてポリプロピレン製バンドで結束したものである. 最下段の段ボール箱内のパックを 1 個取り除き,そのスペー スに輸送環境記録計（DER-mini，神栄テクノロジー. 寸法 $130 \times 90 \times 62 \mathrm{~mm}$, 重量約 $800 \mathrm{~g}$ ) を貼り付け (第 1 図), 輸 送中の衝撃発生状況を調査した。包装の総重量は約 $5.3 \mathrm{~kg}$ であった．記録計の設定条件は，フレーム長： 512 ポイン ト，サンプリング周期 : $1.0 \mathrm{ms,} \mathrm{フィルタモード} \mathrm{:} \mathrm{PASS} \mathrm{お}$ よびデットタイム：1 s とし, トリガレベル設定より $2 \mathrm{G}$ $\left(1.0 \mathrm{G}=9.80665 \mathrm{~m} \cdot \mathrm{s}^{-2}\right)$ 以上の上下・左右・前後 3 方向の 加速度をそれぞれ衝撃として記録した。

\section{2. 落下の高さと衝撃加速度との関係（実験 2) \\ 1）包装形態}

ここでは，国内輸送に扮いて一般的に用いられている包 装形態を用いた.すなわち果実を 2 段詰めした PET 製パッ ク（外寸 $115 \times 170 \times 50 \mathrm{~mm})$ を段ボール箱 $($ JIS Z1507, 0425) に 4 個ずつ梱包し，さらにその段ボール箱を 5 個積み重ね てポリプロピレン製バンドで結束したものである. 包装の 総重量は約 $6.0 \mathrm{~kg}$ であった.

\section{2）落下の試験条件}

落下高さは $0.05,0.10,0.15,0.20,0.25,0.30$ 扎よび $0.35 \mathrm{~m}$ とした. $0.05 〜 0.15 \mathrm{~m}$ では手動で鉄板上に落下させたが, $0.20 \mathrm{~m}$ 以上の高さでは包装容器を手動で垂直に落下させる ことが困難であったため, 落下試験機（DTS-50, 神栄テク
ノロジー）を用いた。

\section{3）衝撃加速度の計測方法}

パック内底面中央部に衝撃計側解析システム（SMH-12, 神栄テクノジー）に接続された 3 次元加速度センサー

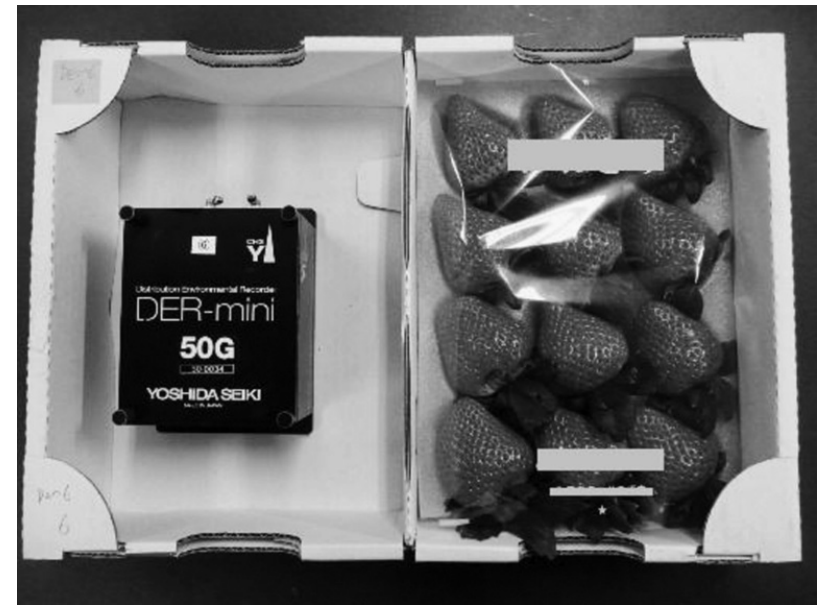

第 1 図輸送工程に打ける衝撃発生状況の調査における記録 計の設置方法
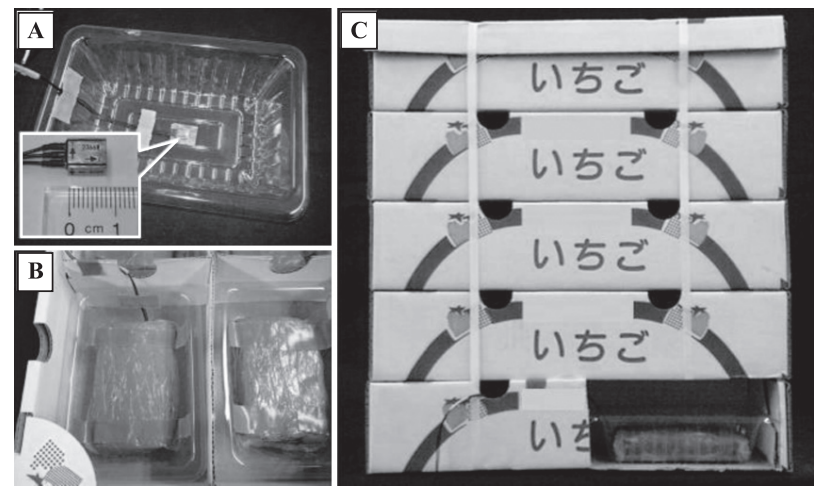

第 2 図落下時における衝撃加速度の計測方法

A : 加速度センサーのパック底面への貼り付け方法,

B : 粘土による加速度センサーの固定と重量の調整,

$\mathrm{C}$ : 箱内に配置されたパック 
（2366W，昭和測器. 寸法 $8.0 \times 7.0 \times 5.5 \mathrm{~mm}$, 重量 $1.2 \mathrm{~g}$ ) を 両面テープで貼り付け（第 2 図 A)，その上から粘土を詰め て固定した (第 2 図B).これを段ボール箱に相包し，1（最 下段）～5 段目（最上段）の箱内に配置することにより（第 2 図 C), 落下時に各段のパックに係る衝撃加速度を計測し た. 各箱内の残り 3 パック分のスペースには粘土のみを詰 めたパック（ダミー）を配置した。 供試した包装形態にお ける $2 \mathrm{~L}$ 等級のイチゴ 1 パックあたりの重さは $300 ３ 20 \mathrm{~g}$ の範囲にあったため，いずれのパックも重量が $320 \mathrm{~g}$ とな るように調整した. 計測された衝撃加速度を衝撃・振動解 析ソフトゥェア（SMS-500, 神栄テクノロジー）に入力し, 3 次元方向の衝撃加速度を合成することによりパックに生 じた最大の衝撃加速度を算出した。

\section{3. 衝撃加速度および衝撃繰り返し回数の違いが果実の損 傷発生に及ぼす影響（実験 3） \\ 1）供試材料}

茨城県内で生産され 2 日以内に収穫された“とち扔とめ” の果実（等級 $2 \mathrm{~L}$ ）を用いた. あらかじめ目視による選抜 を行い, 傷や腐敗が発生しているものや奇形果を除去した. さらに, その中から着色程度 $90 \%$ 以上の果実の久を選抜し， 試験に供した。このような選抜を経た果実の硬度計（KM1 , 藤原製作所）で測定した平均果肉硬度（円筒形プラン ジャー（5 mm 径）貫通時の最大抵抗力）は $0.57 \pm 0.01 \mathrm{~kg}$ であった. 果実は 1 パック当たり 15 個詰め（上段: 3 果 $\times 3$ 列，下段：2果 $\times 3$ 列）とした.

\section{2) 損傷評価}

試験に際し，イチゴの衝撃による損傷を判定するための 基準に関する知見が見出せなかった. そのため, 本実験に おいては ISO 4180-1 付属書（1980）飞記載された損傷の数 值化方法を参考に果実を落下させた際のオ七傷，変形およ び果汁滲出の発生状況を以下の評点により数值化し, 評価 することとした.

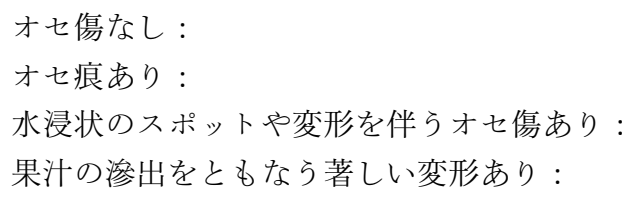

包装形態は実験 2 飞準じ, パック下段の果実を調査対象とし た. 実験 2 の結果に基づいて数段階設定した衝撃加速度を繰 り返し印加した際のパック下段に配置した全果実の評点を 平均化し， 1 果当たりの評点が市販品の平均值である 2.9 (予 め 6 果 $\times 30$ パックについて調査を行い算出）を上回った際に 商品性が喪失したと判定した。 反復数は 3 とした.

\section{3）損傷発生の予測式}

S-N 曲線理論（岩元ら，1980）より, 衝撃の繰り返しに よる果実の損傷を疲労破壊の一種であると仮定すると, 衝 撃加速度 $G$ と果実の商品性が喪失するまでの衝撃繰り返し 回数 $T$ との関係は以下の式で表される.

$$
T=c G^{-b}
$$

ここで， $c$ 抢よび $b$ は定数である. 実験 $3 ， 2 ）$ の結果を式 （1）に当てはめ, 商品性喪失に係る予測式を作成した.

\section{4）実輸送経路における損傷発生箇所の予測}

実験 3，3）の理論より, ある衝撃加速度が発生した際に $N$ 回の衝撃により果実の商品価值が喪失すると仮定する と, 1 回の衝撃につき蓄積される損傷は $N^{-1}$ となる. 従っ て, $n$ 回衝撃が繰り返された際の果実の損傷度 $D$ は

$$
D=n N^{-1}
$$

と定義される．実験 1 の輸送経路に沶いて計測された衝撃 加速度を積算し, 損傷度 $D$ の総和が 1 となる地点を商品価 值が喪失する箇所とした。予測に際し，実験 1 で用いた輸 送環境記録計と実験 2 以降で用いた加速度センサーとの違 いによる計測値の差異が想定された． Ishikawa ら（2009） は，実験 1 で用いた輸送環境記録計を本調查と同一重量の 包装容器に同一の取り付け方法（箱内底面に貼り付け）で 使用した場合, $0.20 \mathrm{~m}$ の高さから容器を落下させた際の衝 撃加速度が約 $50 \mathrm{G}$ であったことを報告している。 そのた め, この報告に打ける加速度值と実験 2 亿打いて包装容器 を $0.20 \mathrm{~m}$ の高さから落下させた際に計測された衝撃加速度 を比較し, 実験1の経路における衝撃の積算値の補正を行つ た後に式（2）を用いた予測を行うこととした.

\section{4. 底面緩衝材による衝撃および果実損傷の軽減効果 (実験 4) \\ 1) 緩衝材}

一般的な発泡ウレタンシート（密度 $15 \mathrm{~kg} ・ \mathrm{~m}^{-3}, 25 \%$ 圧 縮応力 $1.85 \mathrm{kPa}$ ）を用いた，厚さは 5,10 㧊よび $15 \mathrm{~mm}$ の 3 種類とした。緩衝材は段ボール箱内底面とパックとの間 に配置した.

\section{2）緩衝材による衝撃加速度および果実損傷の軽減効果}

各厚さの緩衝材を 1 段目の箱内底面に緩衝材を配置した 際における衝撃掞よび果実損傷の軽減効果について, 実験 2 打よび 3 亿準じた調查を行った。

\section{結果および考察}

\section{1. 輸送工程における衝撃発生状況の調査（実験 1)}

各行程に扔ける衝撃発生状沉を第 3 図に示す。陸路に打 ける衝撃加速度抢よび衝撃発生回数についてその詳細をみ ると, 国内の行程においては衝撃の大半は $5 \mathrm{G}$ 未満であっ た (第 2 表)。このよらな軽微な衝撃はトラック走行中に括 ける道路の輬や継ぎ目（Lu ら，2008）によるものと考兄ら れた。 また，時折 $20 \mathrm{G}$ を超觉る衝撃の発生が認められた が，日本国内に拈けるトラックの走行中においては，この レベルの衝撃発生は考光難い（Lu ら，2008; Nei ら，2008）. さらに, これらの衝撃が発生する前後に全く衝撃が発生し ていない時間帯, すなわち輸送が停止していたと考兄られ る時間帯を伴ら傾向がみられることから，このような衝撃 
第 2 表 調査した輸送工程にお打衝撃発生頻度

\begin{tabular}{|c|c|c|c|c|c|c|c|}
\hline \multirow{2}{*}{ 行程 } & \multirow{2}{*}{$\begin{array}{l}\text { 衝撃 } \\
\text { 回数 }\end{array}$} & \multicolumn{6}{|c|}{ 衝撃加速度 (G) 区分 } \\
\hline & & $2-5$ & $5-10$ & $10-20$ & $20-30$ & $30-40$ & $40-50$ \\
\hline 久留米市内～大田市場 & 86 & 67 & 13 & 4 & $-^{\mathrm{z}}$ & 2 & - \\
\hline 大田市場 & 17 & 14 & 3 & - & - & - & - \\
\hline 大田市場～成田国際空港 & 165 & 152 & 13 & - & - & - & - \\
\hline 成田国際空港 & 119 & 82 & 22 & 10 & 2 & 1 & 2 \\
\hline 成田国際空港〜スワンナプーム国際空港 & - & - & - & - & - & - & - \\
\hline スワンナプーム国際空港 & 38 & 33 & 4 & 1 & - & - & - \\
\hline スワンナプーム国際空港〜現地販売店 & 70 & 64 & 1 & 5 & - & - & - \\
\hline 全行程の合計 & 495 & 412 & 56 & 20 & 2 & 3 & 2 \\
\hline
\end{tabular}

z一は計測されなかったことを示す

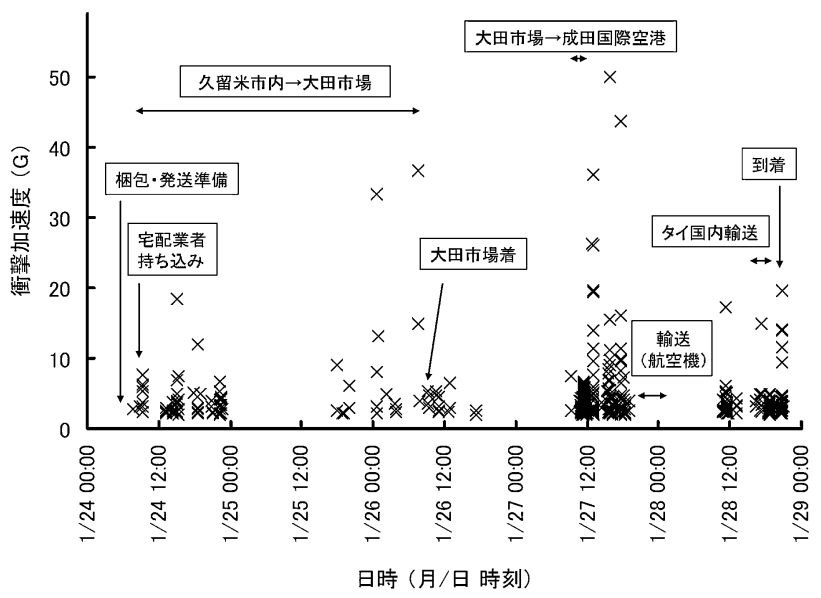

第 3 図調査したイチゴの輸送工程における衝撃加速度の変化

は宅配業者による積荷の中継時などに拈ける荷扱いによる ものと推察される. タイ国内での輸送中に打ける衝撃レベ ル拈よび回数は日本国内のそれらと比較し大きく変わらな かった（第 2 表）.

成田国際空港到着から離陸までの間における衝撃の発生 についてみると, $10 \mathrm{G}$ 以上 $20 \mathrm{G}$ 未満の衝撃が 10 回, $20 \mathrm{G}$ 以上の衝撃が 3 回, $40 \mathrm{G}$ 以上の衝撃が 2 回発生するなど, この行程に打ける衝撃加速度は他の行程と比較して大き かった (第 2 表).オウトウの空路による輸出に打いて, 空 港における包装の積み込みおよび積み降ろし時に高レベル の衝撃が発生することが報告されている（Ishikawaら， 2009). 本調査に扣いては, 飛行機からの積夕降ろし時（ス ワンナプーム国際空港内）に大きな衝撃の発生は考えられ

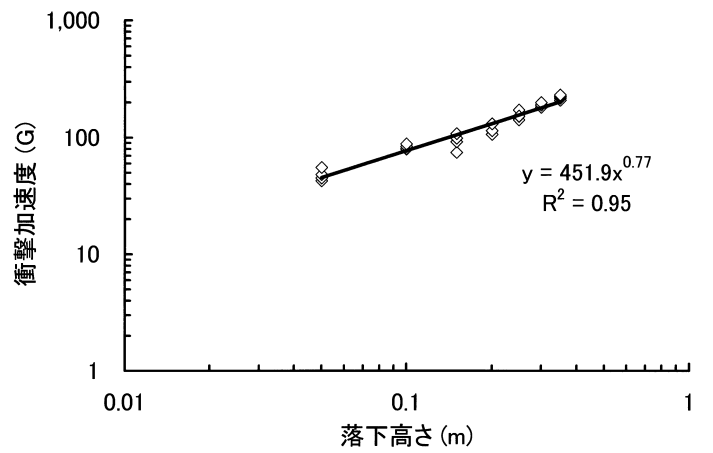

第 4 図落下高さの違いが最下段の箱内に配置したパックに 係る衝撃加速度に及ぼす影響

各点に打ける調査数 $=4$

衝撃加速度の計測に用いたセンサーの違いにより，本

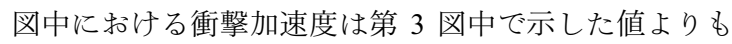
大きくなっている

なかったが，飛行機への積み込み直前の行程において大き な衝撃が発生する点に関して共通の結果となった。成田国 際空港離陸後スワンナプーム国際空港着陸までの空路の行 程において衝撃は確認されなかった（第２表）.

\section{2. 落下の高さと衝撃加速度との関係（実験 2）}

包装容器を $0.05,0.10,0.15,0.20,0.25,0.30$ および $0.35 \mathrm{~m}$ の各高さから落下させた際に 1 段目の箱内のパックに発生 した衝撃加速度は，それぞれ 48，83，94，117，155，193 および $220 \mathrm{G}$ となり (第 4 図)，落下高さ $h(\mathrm{~m})$ と衝撃加 速度 $G$ との関係は，以下の通りとなった.

$$
G=451.9 h^{0.77}\left(\mathrm{R}^{2}=0.95\right)
$$

第 3 表 段ボール箱の位置の違いが落下時にパックに係る衝撃加速度に及ぼす影響

\begin{tabular}{|c|c|c|c|c|c|}
\hline \multirow{2}{*}{ 落下高さ（m） } & \multicolumn{5}{|c|}{ 衝撃加速度（G） } \\
\hline & 1 段目 & 2 段目 & 3 段目 & 4 段目 & 5 段目 \\
\hline 0.20 & $116.7 \pm 4.5^{\mathrm{z}}$ & $57.1 \pm 0.5$ & $39.7 \pm 1.3$ & $36.0 \pm 0.8$ & $35.4 \pm 0.5$ \\
\hline 0.25 & $154.6 \pm 5.5$ & $65.7 \pm 0.7$ & $57.8 \pm 0.4$ & $39.8 \pm 0.8$ & $35.4 \pm 0.7$ \\
\hline 0.30 & $192.7 \pm 3.7$ & $71.8 \pm 1.0$ & $60.4 \pm 2.7$ & $48.1 \pm 1.2$ & $43.9 \pm 1.4$ \\
\hline 0.35 & $220.2 \pm 4.2$ & $81.5 \pm 0.9$ & $64.7 \pm 1.7$ & $57.5 \pm 0.6$ & $45.7 \pm 1.6$ \\
\hline
\end{tabular}

\footnotetext{
$\mathrm{z}$ 平均值 \pm 標準誤差 $(\mathrm{n}=4)$
} 


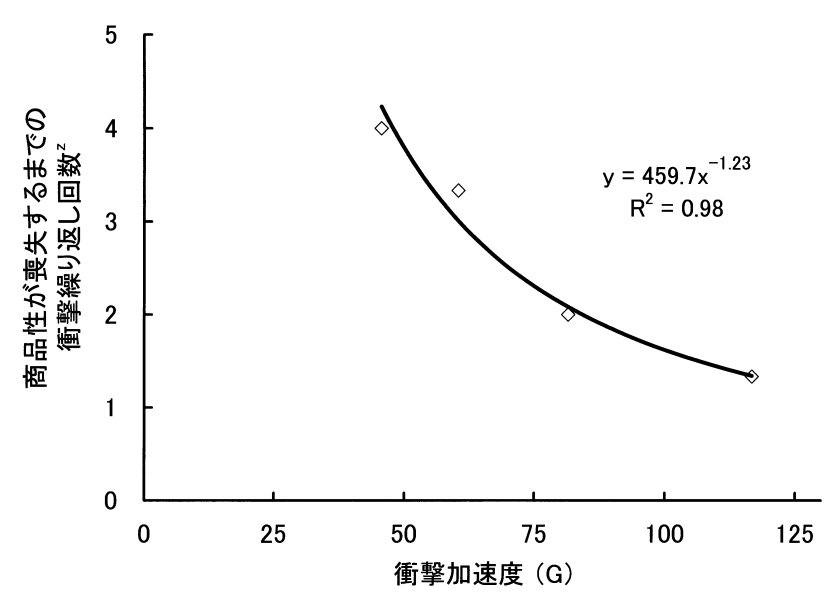

第 5 図 パックに係る衝撃加速度の違いが果実の商品価值が 喪失するまでの衝撃繰り返し回数に及ぼす影響 各值は 3 反復の平均值

z市販品に打ける損傷程度の評点である 2.9 を上回るま での衝撃繰り返し回数

2，3，4 打よび 5 段目の箱内に発生した衝撃加速度は，そ れぞれ，1段目の $37 〜 49 ， 29 ３ 4 ， 26 ３ 1$ および $21 〜$ $30 \%$ 程度となり，1〜2段目の間での減衰が最も大きく，そ の後箱の段数が上がるにつれて, 衝撃加速度はさらに小さ くなった（第 3 表）。石川（2008）はオウトウの $1 \mathrm{~kg}$ 箱を 5 段積み重ねた包装を用いた落下試験に拈いて，1段目の 段ボール箱が一種の緩衝材となり, 上段の段ボール箱に伝 達される衝撃加速度が大幅に減少することを示唆してい る. 従って, 本実験に扮いても落下衝撃の大半は 1 段目の 箱に扣いて吸収されたと考えられた。

\section{3. 衝撃加速度および衝撃繰り返し回数の違いが果実の損 傷発生に及ぼす影響（実験 3）}

実験 2 の結果より，48，60，82 および $117 \mathrm{G}$ の衝撃加速 度を印加した際に拈ける果実の商品性が喪失するまでの平 均落下回数を調査したところ，それぞれ 4.0，3.3，1.7 打よ び 1.3 となった（第 5 図）。これらの結果を式（1）に当ては めると以下の式（4）が得られた.

$$
T=459.7 G^{-1.23} \quad\left(\mathrm{R}^{2}=0.98\right)
$$

この式より，1回の衝撃により確実に商品性が喪失すると予 測される衝撃加速度は $148 \mathrm{G}$ となる.

次に, 式（2）および式（4）より実験 1 の経路で輸送し た際に想定される衝撃加速度の積算值および商品性喪失箇 所の推定を行った. 実験 2 より, この実験に拈ける加速度 センサーは，実験 1 の輸送環境記録計と同一高さから落下 させた場合に，その計測值を 2 倍程度上回る值を示すこと が明らかとなったことから, 第 3 図の衝撃值を 2 倍した上 で推定を行ったところ，1 段目に配置された果実の商品性 は輸送開始から9 時間程度の地点で喪失すると予測された (第 6 図). 従って, もし目的とする輸送工程において商品 性に影響を及ぼすレベルあるいは回数の衝撃が想定される 場合には，包装容器に係る衝撃を軽減する必要があると考

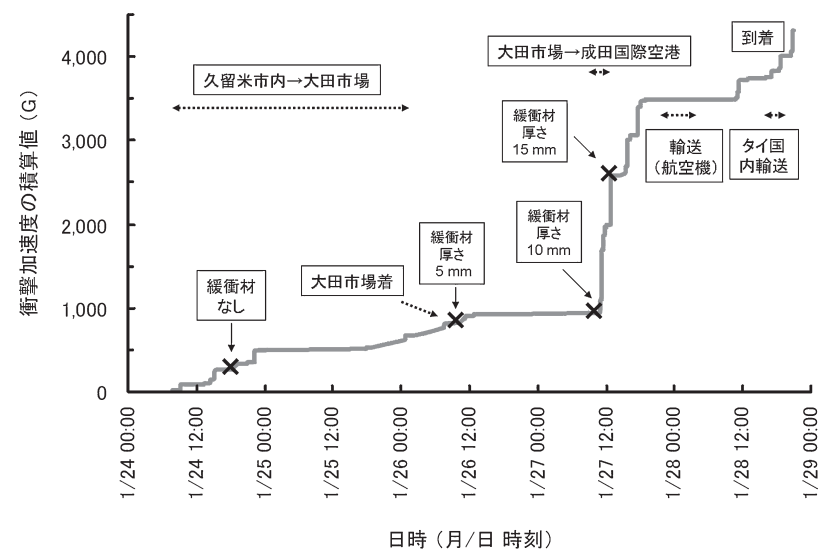

第 6 図イチゴを第 2 図 C の包装形態により実験 1 で調査し た経路で輸送した際に想定される衝撃加速度の積算値 および最下段の箱内に配置された果実の商品性喪失箇 所の予測

図中 $\times$ は, 商品価値が喪失すると予測される箇所を示す 実験 1 と実験 2 での加速度センサーの違いを考慮し, 実 験 1 で得られた衝撃加速度データを2 倍した上で予測值 を算出した

えられ，その一つの方法として包装容器に拈ける緩衝材の 配置が考えられた.

\section{4. 底面緩衝材による衝撃および果実損傷の軽減効果 (実験 4)}

$0.20, \quad 0.25, \quad 0.30$ および $0.35 \mathrm{~m}$ の各高さから包装容器を 落下させた際にパックに係る衝撃加速度は, 緩衝材の厚さ が $5 \mathrm{~mm}$ の場合，それぞれ 46，56，66 抢よび $78 \mathrm{G}$ となっ た (第 7 図)。同様に $10 \mathrm{~mm}$ では，それぞれ $31 ， 41 ， 49$ お よび $59 \mathrm{G}$ となり，15 mm では，それぞれ 22，28，32 拈よ び $39 \mathrm{G}$ となった。 これらの結果より，それぞれの緩衝材を 使用した際に打ける落下高さ $h(\mathrm{~m})$ とパックに係る衝撃 加速度 $G$ との関係は, 以下の通りとなった。

$$
\begin{gathered}
5 \mathrm{~mm}: G=210.6 h^{0.96} \quad\left(\mathrm{R}^{2}=0.95\right) \\
10 \mathrm{~mm}: G=194.7 h^{1.14}\left(\mathrm{R}^{2}=0.99\right) \\
15 \mathrm{~mm}: G=109.2 h^{0.99} \quad\left(\mathrm{R}^{2}=0.97\right)
\end{gathered}
$$

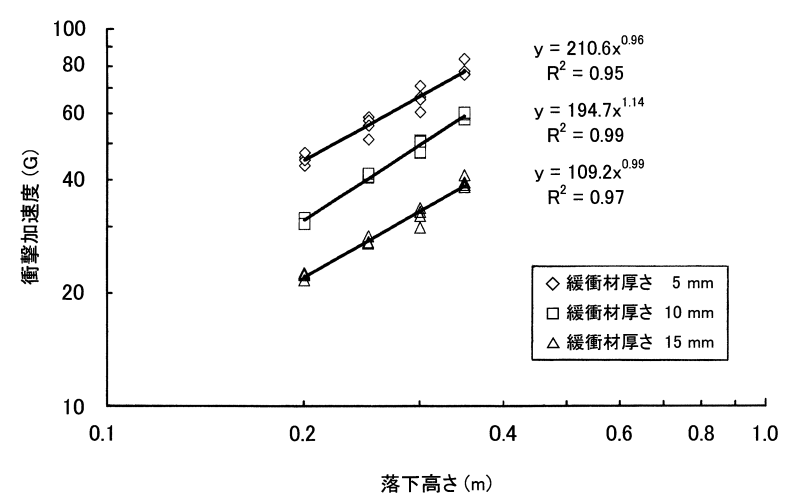

第 7 図緩衝材の厚さの違いが最下段の箱内に配置したパッ クに係る衝撃加速度に及ぼす影響 各点に打ける調査数 $=4$ 
第 4 表 緩衝材による衝撃加速度拈よび果実損傷の軽減効果 ${ }^{\mathrm{z}}$

\begin{tabular}{|c|c|c|c|c|}
\hline \multirow{2}{*}{$\begin{array}{c}\text { 緩衝材の厚さ } \\
(\mathrm{mm})\end{array}$} & \multicolumn{2}{|c|}{ 衝撃加速度（G） } & \multicolumn{2}{|c|}{ 商品性喪失までの落下回数 } \\
\hline & 予測值 & 実測値 & 予測値 & 実測値 \\
\hline $0^{\mathrm{y}}$ & 148.6 & $144.2 \pm 5.3^{x}$ & 1.0 & $1.0 \pm 0.0$ \\
\hline 5 & 52.1 & $52.6 \pm 1.3$ & 3.6 & $3.0 \pm 0.0$ \\
\hline 10 & 37.3 & $36.8 \pm 1.1$ & 5.4 & $5.0 \pm 0.0$ \\
\hline 15 & 27.7 & $25.0 \pm 0.5$ & 8.7 & $8.3 \pm 0.3$ \\
\hline
\end{tabular}

$\mathrm{z}$ 落下の高さ $=0.234 \mathrm{~m}$

$\mathrm{y}$ 緩衝材無し

$\mathrm{x}$ 平均值 \pm 標準誤差 $(\mathrm{n}=3)$

実験 3 亿おいて, 1 度の衝撃で商品性が喪失すると予想され た衝撃加速度とほぼ同等の衝撃加速度 $(148.6 \mathrm{G}$, 落下高さ $=0.234 \mathrm{~m} ）$ を印加した際にパックに係る衝撃加速度は, 緩衝 材の厚さが $5 \mathrm{~mm}$ の場合, 式 (5) より $52.4 \mathrm{G}, 10 \mathrm{~mm}$ では式 （6）より $37.3 \mathrm{G}$ ，そして $15 \mathrm{~mm}$ では式（7）より $27.7 \mathrm{G}$ と予 測された. また式（4）より，これらの衝撃により商品性が 喪失するまでの落下回数は, それ攵れ 3.6, 5.4 打よび 8.7 回 と予測された. 実際にこれらの緩衝材を用いて調査を行った 結果， $3.0 \pm 0.0 ， 5.0 \pm 0.0$ 打よび $8.3 \pm 0.3$ 回となり，打拈むね 予測通りとなった (第 4 表).

これらの結果を, 式（2）抢よび（4）に当てはめ, 実験 1 で調查した行程においてそれぞれの緩衝材を使用した際 の 1 段目の果実に打ける商品性の衰失箇所を予測すると, 緩衝材の厚さを増加させる活ど果実の商品性を維持できる 区間は増加するものの，1 段目の段ボール箱内に配置され たパック内の果実の商品性が成田国際空港に到着するまで 維持される可能性は低いと考兄られた（第6図）。従って, 国内に打ける長距離輸送や輸出を想定した場合，2段詰め 包装以外の包装形態を用いること, 実験 1 に扔いて大きな 衝撃加速度の発生原因と考兄られた積み荷の中継がなるべ く行われない経路を選定することなどの対策が必要である と考えられた。

以上より, 輸送経路や手段ごとの衝撃環境を把握した上 で，実験室内の試験により果実の損傷程度や緩衝材の使用 による衝撃の減衰程度を予め把握しておくことにより, 各 輸送条件下に打ける商品性低下の発生を予測するとともに 対策を講じることが可能になると考えられる.

\section{摘 要}

イチゴの輸送中に想定される衝撃加速度あるいは衝撃発 生回数に対応した損傷防止対策のための基礎的知見を得る ために, イチゴの輸送工程に打ける衝撃加速度和よび衝撃 回数を加速度記録計により調査し, それらがイチゴの商品 性に及ぼす影響を調査した。 さらに，緩衝材の使用による それらの衝撃および果実の商品性低下の軽減効果について 検討した. その結果, 輸送時における衝撃の大半が最下段 の箱に集中することが明らかとなり, 衝撃による損傷防止 のための緩衝包装設計を行う場合, 1 段目（最下段）の包
装容器に係る衝撃加速度拉よび衝撃回数について考慮すべ きであることが示唆された．衝撃加速度と果実の商品性が 喪失するまでの衝撃繰り返し回数との関係は累乗近似曲線 $\left(\mathrm{R}^{2}=0.98\right)$ により表すことができ，この曲線により輸送工 程に拈ける衝撃加速度拈よび衝撃回数が果実の商品性に及 ぼす影響を予測することができた，さらに，この曲線を用 いることにより緩衝材の厚さと衝撃によるイチゴの商品性 低下の軽減程度との関係を明らかにすることができた，以 上の結果より，輸送経路あるいは手段ごとの損傷発生を予 測することができ，的確かつ効率的な損傷防止対策が可能 になると考えられた。

謝 辞 輸送工程に打ける衝撃の計測招よび本文のとり まとめにあたり多大なるご協力を賜った独立行政法人農 業・食品産業技術総合研究機構九州沖縄農業研究七ンター 主任研究員, 曽根一純氏に深謝申し上げる.

\section{引用文献}

石川 豊. 2008. 輸出時に果実が受ける振動・衝撃解析. 農研機構シンポジゥム「国産果実輸出促進を支援する 技術開発の展望」講演要旨集 : 27-31.

Ishikawa, Y., H. Kitazawa and T. Shiina. 2009. Vibration and shock analysis for fruit and vegetables transportationCherry transport from Yamagata to Taiwan by airplane-, JARQ, 43: 129-135.

ISO 4180-1. 1980. Complete, filled transport packages-General rules for the compilation performance test schedules_-Part 1. General principles: appendix.

岩元睦夫・河野澄夫・早川 昭. 1980. 青果物輸送の等価 再現化に関する研究（第3 報）。一損傷に影響する振動 加速度パワースペクトルの評価一. 農機誌. 42: 69-74.

北澤裕明・石川 豊・中村宣貴・椎名武夫. 2008. イチゴ 輸送中の損傷を防止する新たな包装形態. 日食保蔵誌. 34: 19-23.

Lu, F., Y. Ishikawa, T. Shiina and T. Satake. 2008. Analysis of shock and vibration in truck transport in Japan. Packag. Technol. Sci. 21: 479-489.

中村宣貴 - 梅原仁美 - 根井大介 - 岡留博司 - 石川 豊 - 中 野浩平・前澤重禮・椎名武夫. 2008. 包装条件の違い 
がイチゴ果実の損傷に及ぼす影響. 農業施設. 39: 1-8. 中村宣貴 - 梅原仁美 - 岡留博司 - 中野浩平 - 前澤重禮 - 椎 名武夫. 2007. 振動周波数扣よび振動方向がイチゴの 損傷に及ぼす影響. 農業施設. 38: 101-108.

Nei, D., N. Nakamura, P. Roy, T. Orikasa, Y. Ishikawa, H. Kitazawa and T. Shiina. 2008. Wavelet analysis of shock and vibration on the truck bed. Packag. Technol. Sci. 21:
491-499.

農林水産省. 2009. 農林水産物・食品の輸出促進について. 〈http://www.maff.go.jp/j/export/pdf/meguzi_200904_01.pdf〉 Singh, S. P. 1992. New package system for fresh berries. Packag. Technol. Sci. 5: 3-12.

臼田浩幸・椎名武夫 ・石川 豊・佐竹隆顕. 2006. 青果物 の3次元輸送振動シミュレーションのための基礎研究. 農業施設. 36: 215-222. 